\title{
PENGARUH KOMPETENSI KEPRIBADIAN GURU TERHADAP MINAT BELAJAR \\ PENDIDIKAN AGAMA ISLAM (PAI) SISWA KELAS VIII \\ SEKOLAH MENENGAH PERTAMA (SMP) NEGERI 2 PLERED \\ KECAMATAN PLERED KABUPATEN CIREBON
}

\author{
Fahmi Sholehudin, Abdul Ghofar, Akhmad Affandi \\ Fakultas Ilmu Tarbiyah dan Keguruan \\ Institut Agama Islam Negeri Syekh Nurjati Cirebon \\ Email: sholehudin.fahmi@yahoo.com
}

\begin{abstract}
ABSTRAK
Penelitian dalam skripsi ini dilatarbelakangi oleh kurangnya minat belajar siswa dalam mengikuti pembelajaran, Rendahnya minat belajar siswa kelas VIII Sekolah Menengah Pertama (SMP) Negeri 2 Plered ini ditandai dengan beberapa indikator yaitu tidak memperhatikan ketika guru sedang menjelaskan materi, mengobrol dengan temannya, melamun, sibuk dengan aktivitasnya, dan lain-lain. Yang disebabkan oleh faktor yang mempengaruhinya salah satunya adalah kepribadian guru yang mengajarnya. Hal ini yang memberikan efek buruk khususnya terhadap penurunan minat belajar peserta didik.

Penelitian berawal dari kerangka pemikiran bahwa Kompetensi kepribadian guru mencakup sikap, nilai-nilai kepribadian sebagai elemen perilaku dalam kaitannya dengan performance yang ideal sesuai dengan bidang pekerjaan yang dilandasi oleh latar belakang pendidikan, peningkatan kemampuan dan pelatihan, serta legalitas kewenangan mengajar. Sedangkan minat belajar adalah pilihan kesenangan dalam melakukan kegiatan dan dapat membangkitkan gairah seseorang untuk memenuhi kesediannya yang dapat diukur melalui kesukacitaan, ketertarikan, perhatian dan keterlibatan dalam Belajar. Dengan tujuan penelitian untuk mengetahui seberapa besar pengaruh kompetensi kepribadian guru terhadap minat belajar siswa. Jenis data yang digunakan peneliti ialah data kuantitatif. Teknik pengumpulan data yang digunakan antara lain: observasi, wawancara, angket dan dokumentasi. Kesimpulan dari hasil analisis peneliti yaitu terdapat pengaruh yang sangat lemah atau sangat rendah dari pengaruh kompetensi kepribadian guru terhadap minat belajar Pendidikan Agama Islam (PAI) siswa kelas VIII Sekolah
\end{abstract}


Menengah Pertama (SMP) Negeri 2 Plered Cirebon. Berdasarkan hasil perhitungan koefisien korelasi melalui product moment, diperoleh nilai koefisien $r_{x y}$ sebesar 0.08 ternyata terletak antara 0,00 sampai dengan 0,20.

Kata Kunci: Kompetensi Guru, Kepribadian Guru, dan Minat Belajar Siswa 


\section{A. Pendahuluan}

Pendidikan adalah proses yang direncanakan agar semua berkembang melalui proses pembelajaran. Guru sebagai pendidik harus dapat memengaruhi ke arah proses itu sesuai dengan tata nilai yang dianggap baik dan berlaku dalam masyarakat. Tata nilai termasuk norma, moral, estetika, dan ilmu pengetahuan, mempengaruhi perilaku etik siswa sebagai pribadi dan sebagai anggota masyarakat. Penerapan disiplin yang baik dalam poses pendidikan akan menghasilkan sikap mental, watak dan kepribadian siswa yang kuat. Guru dituntut harus mampu membelajakan siswanya tentang disiplin diri, belajar membaca, mencintai buku, menghargai waktu, belajar bagaimana cara belajar, mematuhi aturan/tata tertib, dan belajar bagaimana harus berbuat. Semua itu akan berhasil apabila guru juga disiplin dalam melaksanakan tugas dan kewajibannya. ${ }^{1}$

Kompetensi adalah keseluruhan pengetahuan, sikap, dan keterampilan yang diperlukan oleh seseorang dalam kaitan dengan suatu tugas tertentu. Kompetensi guru ialah pengetahuan, sikap, dan keterampilan yang harus ada pada seseorang guru agar dapat menunjukkan perilakunya sebagai guru. ${ }^{2}$

Kompetensi kepribadian merupakan sejumlah kompetensi yang berhubungan dengan kemampuan pribadi dengan segala karakteristik yang mendukung pelaksanaan tugas guru. Fungsi utama seorang guru adalah sebagai teladan bagi murid-muridnya. ${ }^{3}$

Rif'at Syauqi Nawawi mengulas beberapa ayat Al-Qur'an mengenai kepribadian manusia seperti yang tercantum dalam QS. Asy-Syams (91): 7-10 yang berbunyi:

Artinya: "Dan jiwa serta penyempurnaannya (ciptaannya), maka Allah mengilhamkan kepada jiwa itu (jalan) kefasikan dan ketakwaannya. Sesungguhnya beruntunglah orang yang mensucikan jiwa itu, Dan Sesungguhnya merugilah orang yang mengotorinya."4

Setelah memahami lebih luas apa itu kompetensi inti dari guru dalam penelitian ini, peneliti ingin mengambil salah satu bentuk kompetensi yang dimiliki

${ }^{1}$ Pudjosumedi, dkk. Profesi Pendidikan (Jakarta: Uhamka Press, 2013), 87.

${ }^{2}$ Mohamad Surya, Psikologi Pembelajaran dan Pengajaran (Bandung: Pustaka Bani Quraisy, 2004), 93.

${ }^{3}$ Djam'an Satori, Profesi Keguruan (Jakarta: Universitas Terbuka, 2005), 211.

${ }^{4}$ Departemen Agama RI. Mushaf Al-Qur'an Terjemah Edisi Tahun 2002 (Jakarta: Al Huda, 2005) 596. 
oleh guru salah satunya adalah kompetensi kepribadian. Kompetensi kepribadian merupakan salah satu kompetensi yang harus dimiliki guru agar dapat dijadikan sebagai daya tarik atau minat belajar siswa.

Minat adalah rasa lebih suka dan rasa keterikatan pada suatu hal atau aktivitas, tanpa ada yang menyuruh. Minat pada dasarnya adalah penerimaan akan suatu hubungan antara diri sendiri dengan sesuatu diluar diri. Semakin kuat atau dekat hubungan tesebut, semakin besar minatnya. Crow and Crow mengatakan bahwa minat berhubungan dengan gaya gerak yang mendorong seseorang untuk mengahadapi atau berurusan dengan orang, benda, kegiatan, pengalaman yang dirangsang oleh kegiatan itu sendiri. ${ }^{5}$

Belajar adalah kegiatan yang berproses dan merupakan unsur yang sangat fundamental dalam penyelenggaraan setiap jenis dan jenjang pendidikan. Ini berarti bahwa berhasil atau gagalnya penciptaan tujuan pendidikan itu amat bergantung pada proses belajar yang dialami siswa, baik ketika ia berada di sekolah maupun di lingkungan rumah atau keluarganya sendiri. ${ }^{6}$

Kondisi belajar mengajar yang efektif adalah adanya minat dan perhatian siswa dalam belajar. Minat merupakan suatu sifat yang relatif menetap pada diri seseorang. Minat ini besar sekali pengaruhnya terhadap belajar sebab dengan minat seseorang akan melakukan sesuatu yang diminatinya. Sebaliknya, tanpa minat seseorang tidak mungkin melakukan sesuatu. ${ }^{7}$

Jadi minat belajar adalah rasa lebih suka dan ketertarikan siswa terhadap proses belajar tanpa ada yang menyuruh. Baik suka kepada mata pelajaran, metode, strategi, media, maupun cara guru yang mengajarnya.

Berdasarkan hasil pengamatan di lapangan yang ada, ditemukan suatu permasalahan, yaitu tentang minat belajar siswa pada bidang studi Pendidikan Agama Islam (PAI). Yang dimana banyak siswa yang memiliki semangat yang tinggi untuk belajar, namun faktanya semangat yang ada itu tidak keluar dengan maksimal dari dirinya, karena belum ada faktor yang memengaruhinya, baik internal maupun eksternal.

\footnotetext{
${ }^{5}$ Djaali, Psikologi Pendidikan (Jakarta: Bumi Aksara, 2014), 121.

${ }^{6}$ Muhibbin Syah, Psikologi Pendidikan (Bandung: PT Remaja Rosdakarya, 2013), 87.

${ }^{7}$ Suryo Subroto, Proses Belajar Mengajar (Jakarta: PT Rineka Cipta, 1997), 27.
} 
Berdasarkan hasil wawancara dengan ibu Eer Eryani pada hari Rabu tanggal 25 Januari 2017 di Sekolah Menengah Pertama (SMP) Negeri 2 Plered, bidang studi Pendidikan Agama Islam itu minat belajar siswanya kurang maksimal, misalnya yaitu tidak memperhatikan ketika guru sedang menjelaskan materi, mengobrol dengan temannya, melamun, sibuk dengan aktivitasnya, dll. Yang disebabkan oleh faktor yang memengaruhinya salah satunya adalah kepribadian guru yang mengajarnya. Hal ini yang memberikan efek buruk khususnya terhadap penurunan minat belajar peserta didik.

Kepribadian guru ketika mengajar sudah baik, yaitu sopan dan santun, ketika masuk kelas mengucapkan salam, senyum dan menyapa siswa, berpakaian rapih sesuai dengan aturan. Cara berjalannya pun berwibawa, suaranya ketika mengajar itu lemah lembut. Akan tetapi kurang tegas, dalam artian ketika ada siswa yang tidak memperhatikan, mengobrol dibelakang, sibuk dengan aktivitasnya, melamun, itu dibiarkan saja. Kemudian ketika ada siswa yang terlambat masuk tidak juga ditegur. Hal ini mengakibatkan kebiasaan itu dilakukan terus menerus oleh siswanya.

Berdasarkan dari latar belakang masalah yang dipaparkan diatas, penulis tertarik untuk mengangkat judul tentang "Pengaruh Kompetensi Kepribadian Guru Terhadap Minat Belajar Pendidikan Agama Islam (PAI) Siswa Kelas VIII Sekolah Menengah Pertama (SMP) Negeri 2 Plered Kecamatan Plered Kabupaten Cirebon”.

Perumusan Masalah dari kajian masalah yang penulis temukan, kemudian dirumuskan permasalahannya, sehingga akan dihasilkan karya tulis yang baik. Adapun perumusan masalah yaitu :

1) Apakah kompetensi kepribadian guru di Sekolah Menengah Pertama (SMP) Negeri 2 Plered Kabupaten Cirebon sudah baik?

2) Apa minat belajar Pendidikan Agama Islam (PAI) siswa kelas VIII Sekolah Menengah Pertama (SMP) Negeri 2 Plered Kabupaten Cirebon sudah baik?

3) Apakah ada pengaruh kompetensi kepribadian guru terhadap minat belajar Pendidikan Agama Islam (PAI) siswa kelas VIII Sekolah Menengah Pertama (SMP) Negeri 2 Plered Kabupaten Cirebon?

AdapunTujuan Penelitianyang ingin dicapai pada penelitian ini adalah sebagai berikut:

1. Untuk mengetahui kompetensi kepribadian guru di Sekolah Menengah Pertama (SMP) Negeri 2 Plered Kabupaten Cirebon. 
2. Untuk mengetahui minat belajar Pendidikan Agama Islam (PAI) siswa kelas VIII Sekolah Menengah Pertama (SMP) Negeri 2 Plered Kabupaten Cirebon.

3. Untuk mengetahui pengaruh kompetensi kepribadian guru terhadap minat belajar Pendidikan Agama Islam (PAI) siswa kelas VIII Sekolah Menengah Pertama (SMP) Negeri 2 Plered Kabupaten Cirebon.

Langkah-langkah dalam penelitian ini yaitu: observasi, observasi dilakukan untuk memperoleh data tentang hal-hal yang terkait dengan sekolah dan hal-hal yang terkait dengan kepribadian guru dan minat belajar siswa. Wawancara, untuk memperoleh data tentang pengaruh kompetensi kepribadian guru terhadap minat belajar siswa. Penyebaran angket, untuk mengetahui seberapa besar pengaruh kompetensi kepribadian guru terhadap minat belajar siswa . Dan dokumentasi, untuk mencatat dan memotret segala hal yang berkaitan dengan kepribadian guru dan minat belajar siswa.

\section{B. Pengaruh Kompetensi Kepribadian Guru terhadap Minat Belajar Pendidikan}

\section{Agama Islam (PAI)}

Penelitian ini dilaksanakan di SMP Negeri 2 Plered Kabupaten Cirebon yang bertempat di Jalan Otista Tegalsari Plered Kabupaten Cirebon. Adapun waktu penelitian dilaksanakan pada semester Genap tahun ajaran 2016/2017, yaitu dimulai dari bulan Maret sampai dengan bulan Mei 2017.

Penelitian ini dilaksanakan di Sekolah Menengah Pertama (SMP) Negeri 2 Plered Kabupaten Cirebon terletak di Jalan Otista Tegalsari Plered Kecamatan Plered Kabupaten Cirebon dan telah beroperasi sejak tahun 2005. Kepemilikan tanah atau bangunan merupakan milik pemerintah Kabupaten Cirebon. Yang berdiri diatas tanah seluas $9000 \mathrm{~m}^{2}$ dan memiliki bangunan seluas $6279 \mathrm{~m}^{2}$.

Sekolah Menengah Pertama (SMP) Negeri 2 Plered Kabupaten Cirebon saat ini dipimpin oleh H. Ustadz MJ., S.Ag. M.A, No Telepon (0231) 320720 dan kode POS 45158. Secara deskriptif SMP Negeri 2 Plered Kabupaten Cirebon terletak/berdampingan dengan SD Negeri 3 Tegalsari Kabupaten Cirebon..Untuk lebih jelasnya dibawah ini:

Waktu penelitian berdasarkan Surat Keputusan oleh Dekan Fakultas Ilmu Tarbiyah dan Keguruan (FITK) Nomor: 2047/in.08/F.I. I/PP.009/03/2017 
terhitung mulai tanggal 27 Maret sampai dengan 27 Mei 2017. Penelitian ini dilakukan selama 1 bulan mulai tanggal 27 Maret sampai dengan 27 April 2017.

Sumber data teoritik, yaitu data yang diperoleh dari buku-buku yang ada hubungannya pekerjaan orang tua dengan prestasi belajar sebagau sumber rujukan.

Sumber data empirik, yaitu data yang diperoleh dari lokasi penelitian di Sekolah Menengah Pertama (SMP) Negeri 2 Plered Kabupaten Cirebon yaitu kepala sekolah, Guru Pendidikan Agama Islam (PAI), wali kelas, staf Tata Usaha (TU) dan siswa.

Penelitian ini termasuk jenis penelitian Kuantitatif. Penelitian kuantitatif adalah jenis penelitian yang mengandalkan pada pengindraan empiris atau pengolahan data melalui hitungan angka dalam matematika. Penelitian kuantitatif juga dapat diartikan sebagai penelitian dengan menggunakan analisis data berupa perhitungan secara matematis. Ciri utamanya adalah menggunakan data statistik karena menggunakan atau menerapkan rumus dan cara kerja ilmu statistik.

Penelitian kuantitatif didasari oleh filsafat positivisme yang menekankan fenomena-fenomena objektif dan dikaji secara kuantitatif. Maksimalisasi objektivitas desain penelitian ini dilakukan dengan menggunakan angka-angka, pengolahan statistik,struktur dan percobaan terkontrol. Ada beberapa metode penelitian yang dapat dimasukkan kedalam penelitian kuantitatif yang bersifat noneksperimental, yaitu metode: deskriptif, survai, ekspos fakto, komparatif, korelasional dan penelitian tindakan.

Berdasarkan pengertian penelitian kuantitatif di atas penulis dapat menyimpulkan bahwa penelitian kuantitatif adalah penelitian yang pengumpulan datanya menggunakan angka-angka atau statistik karena pada saat mengerjakan atau mengumpulkan data menggunakan, menerapkan, mengolah rumus. selain itu mengutamakan desain dan metode kerja yang ketat agar data yang didapatkan akurat.

Menurut Arikunto populasi adalah keseluruhan objek penelitian. ${ }^{8}$ Dan dalam penelitian ini mengambil populasi yaitu seluruh Siswa Kelas VIII Sekolah

${ }^{8}$ Suharsimi Arikunto, Prosedur Penelitian Suatu Pendekatan Praktik (Jakarta: Rineka Cipta, 2010), 102. 
Menengah Pertama (SMP) Negeri 2 Plered Kabupaten Cirebon, dari kelas VIII AJ berjumlah 328 siswa.

Sampel adalah sebagian atau wakil populasi yang diteliti. Dinamakan penelitian sampel apabila kita bermaksud untuk menggeneralisasikan hasil penelitian sampel. ${ }^{9}$

Penelitian ini menggunakan teknik sampling cluster sampling, sampel terdiri dari sekelompok anggota yang terhimpun pada gugusan (cluster), bukan anggota populasi yang diambil secara satu persatu (secara individual). ${ }^{10}$

Penentuan sampel penelitian ini adalah Siswa kelas VIII F yang berjumlah 34 siswa Sekolah Menengah Pertama (SMP) Negeri 2 Plered Kabupaten Cirebon seperti disarankan Arikunto, yaitu:

"Untuk sekedar ancer-ancer maka apabila subjeknya kurang dari 100, lebih baik diambil semua sehingga penelitiannya merupakan penelitian populasi. Selanjutnya jika jumlah subjeknya besar dapat diambil antara 10-15\% atau 20$25 \%$ atau lebih menurut kemampuan peneliti." 11

Penelitian ini memiliki dua varabel, yaitu variabel independen dan variabel dependen. Variabel independen (variable bebas) merupakan variabel yang memengaruhi variabel lain, yang pada umumnya berada dalam urutan tata waktu yang terjadi lebih dulu. Variabel ini biasanya disimbolkan dengan variabel "x", sedangkan yang dimaksud dengan variabel dependen (variable terikat) merupakan variabel yang diakibatkan atau dipengaruhi oleh variabel bebas. Penelitian ini biasanya disimbolkan dengan variabel " $y$ ".

Penelitian ini terdapat dua variabel yang dijadikan sebagai acuan dalam pengamatan, guna memperoleh data dan kesimpulan empiris mengenai pengaruh kegiatan ekstrakurikuler Rohis dengan prestasi belajar :

a. Variabel independen (variabel bebas) yaitu kompetensi kepibadian guru sebagai variabel $\mathrm{X}$.

b. Variabel dependen (variabel terikat) yaitu minat belajar siswa sebagai variabel Y.

Definisi Konseptual

\footnotetext{
${ }^{9}$ Suharsimi Arikunto, Prosedur Penelitian Suatu Pendekatan Praktik 131.

${ }^{10}$ Mohammad Ali, Penelitian Kependidikan Prosedur \& Strategi (Bandung: Angkasa, 2013), 74.

${ }^{11}$ Suharsimi Arikunto, Prosedur Penelitian Suatu Pendekatan Praktik, 120.
} 
1) Kompetensi Kepribadian Guru (Variabel $X$ )

Kompetensi personal, ialah kualitas kemampuan pibadi seorang guru yang diperlukan agar dapat menjadi guru yang baik. Kompetensi personal ini mencakup kemampuan pribadi yang berkenaan dengan pemahaman diri, penerimaan diri, pengarahan diri, dan perwujudan diri. ${ }^{12}$

2) Minat Belajar Siswa (Variabel Y)

Minat adalah perasaan ingin tahu, mempelajari, mengagumi atau memiliki sesuatu. Disamping itu, minat merupakan bagian dari ranah afeksi, mulai dari kesadaran sampai pada pilihan nilai. Holland mengatakan, minat adalah kecenderungan hati yang tinggi terhadap sesuatu. Minat tidak timbul sendirian, ada unsur kebutuhan, misalnya minat belajar, dan lainlain. ${ }^{13}$

\section{Definisi Operasional}

1) Kompetensi Kepribadian Guru (Variabel X)

Kompetensi kepribadian guru mencakup sikap, nilai-nilai kepribadian sebagai elemen perilaku dalam kaitannya dengan performance yang ideal sesuai dengan bidang pekerjaan yang dilandasi oleh latar belakang pendidikan, peningkatan kemampuan dan pelatihan, serta legalitas kewenangan mengajar. ${ }^{14}$

\section{2) Minat Belajar Siswa (Variabel Y)}

Minat berarti kecenderungan dan kegairahan yang tinggi atau keinginan yang besar terhadap sesuatu. Menurut Reber (1988), minat tidak termasuk istilah populer dalam psikologi karena kebergantungannya yang banyak pada faktor-faktor internal lainnya seperti: pemusatan perhatian, keingintahuan, motivasi, dan kebutuhan. ${ }^{15}$

Teknik pengumpulan data dalam penelitian ini yaitu: observasi, wawancara, angket, dan dokumentasi

Observasi adalah suatu proses yang kompleks, atau proses yang tersususun dari berbagai proses biologis dan psikologis, dua diantaranya yang terpenting

${ }^{12}$ Mohamad Surya, Psikologi Pembelajaran dan Pengajaran, 94.

${ }^{13}$ Djaali, Psikologi Pendidikan, 122.

${ }^{14}$ Djam'an Satori, Profesi Keguruan, 24.

${ }^{15}$ Muhibbin Syah, Psikologi Pendidikan, 133. 
adalah proses-proses pengamatan dan ingatan. ${ }^{16}$ Sedangkan menurut Suprijono metode observasi adalah cara pengumpulan data dalam rangka penyelidikan terhadap tingkah laku sosial dalam situasi sosial yang wajar.

Melalui teknik observasi ini, penulis berusaha mengamati, mencatat, dan mendengarkan kenyataan yang berkenaan dengan letak geografis, sejarah, kondisi lingkungan sekolah dan hal-hal yang terkait dengan sekolah dan juga hal-hal yang terkait dengan pengaruh kompetensi kepribadian guru terhadap minat belajar siswa.

Wawancara: Metode wawancara ini diperlukan dengan alasan untuk mengetahui apa yang sebenarnya terjadi pada minat belajar siswa, dan orang yang paling mengerti adalah guru yang mengajarnya. Wawancara adalah metode penelitian yang dilakukan dengan jalan tanya jawab dengan objek secara Face to Face atau tatap muka dengan mengadakan pencatatan-pencatatan. Sedangkan menurut Gardon W. Aiiport metode wawancara adalah untuk mengumpulkan data yang meliputi perasaan, pengalaman, apa yang diingat, dorongan dan alasan bertingkahlaku dari individu.

Adapun yang menjadi sumber data dalam wawancara ini adalah digunakan untuk memperoleh kebenaran kompetensi kepribadian guru dengan minat belajar Pendidikan Agama Islam siswa kelas VIII Sekolah Menengah Pertama (SMP) Negeri 2 Plered Kabupaten Cirebon. Dalam penelitian ini, penulis mengadakan wawancara dengan guru yang bersangkutan, guru PAI, kepala sekolah, wakil kepala sekolah..

Angket (questioner): adalah daftar pertanyaan yang diberikan kepada orang lain yang bersedia menerima respond sesuai keinginan pengguna. Dalam penelitian ini, penulis menyebarkan daftar pernyataan tertulis kepada siswa kelas VIII F SMP Negeri 2 Plered yang minat belajarnya rendah, yang dijadikan sebagai responden dalam penelitian ini.

Tabel: 1

Bobot Skor Skala Likert

\section{Jawaban Alternatif Skor Pernyatan Positif}

${ }^{16}$ Sugiyono, Metode Penelitian Pendidikan (Alfabeta.: Bandung, 2010), 203. 


\begin{tabular}{cc}
\hline Selalu & 4 \\
Sering & 3 \\
Kadang-kadang & 2 \\
Tidak pernah & 1 \\
\hline
\end{tabular}

Sumber: SMP 3 Cirebon tahun 2017.

Dokumentasi: adalah catatan tertulis tentang berbagai kegiatan atau peristiwa pada waktu yang lalu. Dalam penelitian ini yang dimaksud dokumentasi adalah metode pengumpulan data dengan jalan melihat catatan yang sudah ada. Metode dokumentasi diperlukan sebagai metode pendukung untuk mengumpulkan data.

Teknik analisis data merupakan proses penyederhanaan ke dalam bentuk yang lebih mudah dibaca dan diinterprestasikan. Untuk mengetahui bagaimana pengaruh kompetensi kepribadian guru terhadap minat belajar Pendidikan Agama Islam siswa kelas VIII. Maka dalam analisa data ini penulis menggunakan nilai ratarata sebagai pembatas, sebagaimana yang diutarakan oleh Suharsimi Arikunto yaitu $^{17}$ :

a. Nilai yang berada di atas rata-rata menunjukkan kategori "Tinggi" disingkat T.

b. Nilai rata-rata dan lebih rendah dari rata-rata menunjukkan kategori "Rendah", disingkat R.

Adapun dalam menganalisa data tentang pengaruh variable $\mathrm{X}$ terhadap variabel Y menggunakan rumus korelasi“"productmoment”, yaitu hubungan antara dua variabel sebagai berikut:

$$
r_{x y}=\frac{N \sum X Y-\left(\sum X\right)\left(\sum Y\right)}{\sqrt{\left\{N \sum X^{2}-\left(\sum X\right)^{2}\right\}\left\{N \sum Y^{2}-\left(\sum Y\right)^{2}\right\}}}
$$

Keterangan:

$r_{x y} \quad$ : angka indeks korelasi " $\mathrm{r}$ " product moment

$N \quad$ : jumlah responden

$\sum X Y \quad$ : jumlah hasil perkalianantara skor Xdan $\mathrm{Y}$

$\sum \mathrm{X} \quad$ : jumlahseluruhskor $\mathrm{X}$

$\sum \mathrm{Y} \quad$ : jumlahseluruh skor $\mathrm{Y}$

${ }^{17}$ Suharsimi Arikunto, Prosedur Penelitian Suatu Pendekatan Praktik, 296. 
Selanjutnya untuk memberikan interpretasi secara sederhana angka indeks korelasi "r"product moment $\left(\mathrm{r}_{\mathrm{Xy}}\right)$ diperlukan pedoman sebagai berikut:

Tabel.10

\begin{tabular}{ll}
\hline IntervalKoefisien & TingkatHubungan \\
\hline $0,00-0,20$ & Sangat Rendah \\
$0,20-0,40$ & Rendah atau Lemah \\
$0,40-0,70$ & Sedang \\
$0,70-0,90$ & Kuat atau Tinggi \\
\hline
\end{tabular}

Penelitian ini memiliki hipotesis statistik dalam bentuk $\mathrm{H}_{\mathrm{o}}$ (diterima) dan $\mathrm{H}_{\mathrm{a}}$ (ditolak). Adapun $\mathrm{H}_{\mathrm{o}}$ dalam penelitian ini "tidak ada pengaruh yang signifikan dari kompetensi kepribadian guru terhadap minat belajar". Dan $\mathrm{H}_{\mathrm{a}}$ ada pengaruh yang signifikan dari kompetensi kepribadian guru terhadap minat belajar".

Berdasarkan penelitian ini tentang variabel X (kompetensi kepribadian guru) dan variabel Y (minat belajar), setelah dibuktikan dan dianalisis dengan hasil persetujuan kategori sangat lemah atau sangat rendah, korelasi product moment menunjukkan nilai yang positif yaitu 0,084. Akhirnya dapat dikemukakan kesimpulan, bahwa $r_{\text {hitung }} 0,084$ berada dibawah $r_{\text {tabel }}$ yaitu sebesar 0,349 , baik pada tafsir signifikansi $5 \%$ ataupun $1 \%$, maka hipotesisi di atas secara statistic diterima $\left(\mathrm{H}_{\mathrm{o}}\right)$, yang berarti ada tidak ada pengaruh yang signifikan dari kompetensi kepribadian guru terhadap minat belajar. Setelah diketahui koefisien korelasi di atas, maka dapat diketahui nilai t hitung sebagai berikut:

$$
t_{\text {hitung }}=\frac{r \sqrt{n-2}}{\sqrt{1-r^{2}}}
$$

$$
\begin{aligned}
& =\frac{0,08 \sqrt{34-2}}{\sqrt{1-0,08^{2}}} \\
& =\frac{0,08 \sqrt{32}}{\sqrt{1-0,08^{2}}}
\end{aligned}
$$




$$
\begin{aligned}
& =\frac{(0,08)(5,65)}{1-0,0064} \\
& =\frac{0,452}{0,9936} \\
& =0,45
\end{aligned}
$$

Mencari t Tabel dengan $\alpha=0,05$

$\mathrm{df}=(\mathrm{n}-2=34-2)=32$

$32=1,693$

Maka : $\mathrm{t}$ hitung $=0,45<\mathrm{t}$ tabel $=1,693$

Uji hipotesis menjawab bahwa jika thitung lebih kecil dari pada ttabel artinya hipotesis yang menjawab bahwa tidak terdapat pengaruh antara Kompetensi Kepribadian Guru terhadap Minat Belajar ditolak.

\section{Kesimpulan}

Berdasarkan hasil penelitian tentang Pengaruh Kompetensi Kepribadian Guru Terhadap Minat Belajar Pendidikan Agama Islam (PAI) Siswa Kelas VIII F Sekolah Menengah Pertama (SMP) Negeri 2 Plered Kecamatan Plered Kabupaten Cirebon yang telah dilakukan dapat disimpulkan sebagai berikut :

Kompetensi kepribadian guru mata pelajaran Pendidikan Agama Islam (PAI) sudah cukup. Hal ini terbukti dari hasil rata-rata pencapian pengaruh kompetensi kepribadian guru yang sebagian besar berada pada kategori baik sekali dengan ratarata prosentase pencapaian sebesar $85 \%$ karena berada pada rentang $81 \%$ - 100\%.

Minat belajar siswa kelas VIII F dalam pembelajaran Pendidikan Agama Islam (PAI) di Sekolah Menengah Pertama (SMP) Negeri 2 Plered Kecamatan Plered Kabupaten Cirebon sudah cukup. Hal ini terbukti dari hasil rata-rata pencapaian disiplin belajar siswa sebagian besar berada pada kategori baik dengan nilai rata-rata prosentase pencapaian sebesar 64,5 karena berada pada rentang 61\% - 80\%, ini membuktikan bahwa sebagian besar minat belajar siswa pada studi Pendidikan Agama Islam (PAI) di Sekolah Menengah Pertama (SMP) Negeri 2 Plered Kecamatan Plered Kabupaten Cirebon dipengaruhi oleh pengaruh kompetensi kepribadian guru.

Terdapat pengaruh yang positif antara kompetensi kepribadian guru dengan minat belajar siswa pada studi pembelajaran Pendidikan Agama Islam (PAI) kelas VIII F di Sekolah Menengah Pertama (SMP) Negeri 2 Plered Kecamatan Plered Kabupaten Cirebon dikategorikan sangat lemah atau sangat rendah dengan ${ }^{t}$ hitung 
sebesar 0,08 ternyata terletak pada interval $0,00-0,20$. Berdasarkan kriteria tersebut maka makna koefisien korelasi termasuk kedalam kategori korelasi yang sangat lemah atau sangat rendah sedangkan sisanya $92 \%$ dipengaruhi faktor lain, seperti lingkungan, teman, masyarakat dan lainnya. 


\section{DAFTAR PUSTAKA}

Ali, Mohammad. Penelitian Kependidikan Prosedur \& Strategi, cet. III. Bandung: Angkasa, 2013.

Arikunto, Suharsimi, 2010. Prosedur Penelitian Suatu Pendekatan Praktik. Jakarta: Rineka Cipta.

Departemen Agama RI. 2005. Mushaf Al-Qur'an Terjemah Edisi Tahun 2002. Jakarta: Al Huda.

Djaali, 2014. Psikologi Pendidikan. Jakarta: Bumi Aksara.

Pudjosumedi, dkk. 2013. Profesi Pendidikan. Jakarta: Uhamka Press.

Satori, Djam'an, 2005. Profesi Keguruan. Jakarta: Universitas Terbuka.

Subroto, Suryo, 1997. Proses Belajar Mengajar. Jakarta: PT Rineka Cipta.

Sugiyono, 2010. Metode Penelitian Pendidikan. Alfabeta.: Bandung.

Surya, Mohamad, 2004. Psikologi Pembelajaran dan Pengajaran. Bandung: Pustaka Bani Quraisy.

Syah, Muhibbin, 2013. Psikologi Pendidikan. Bandung: PT Remaja Rosdakarya. 